\title{
COLOUR TERM 'BLACK' IN ESTONIAN PLACE NAMES
}

\author{
Kaidi Rätsep \\ Institute of the Estonian Language, Tallinn, \\ and the University of Tartu
}

\begin{abstract}
Must 'black' is considered to be the most common colour attribute in place names. The article provides a brief overview of must 'black' in Estonian place names. The data was obtained from kohanimekartoteek 'place names card index' of the Institute of the Estonian Language. In the index there are 1377 slips beginning with (or containing) must 'black', discounting within-parish duplicate slips 1081 place names were found. Altogether, 728 different place name variants were discovered. The most frequent occurrences of must in the nominative case were Mustjogi 'Black-river' (frequency = 26), Mustjärv 'Black-lake' (22), Mustkivi 'Black-stone' (21), Mustoja 'Black-rivulet' (18) and Mustmägi 'Black-hill' (16). In the genitive case Musta talu 'Black farm' (22) was twice as frequent as the next most common, Musti talu 'Musti farm' (11). According to the studied material the most common determinant was talu 'farm' (231), followed by mägi 'hill' (70), mets 'forest' (45) and heinamaa 'hayfield' (43).
\end{abstract}

Keywords: place names, must 'black', colour attribute, Estonia

\section{Introduction}

The idea of searching kohanimekartoteek 'place names card index' of the Institute of the Estonian Language, for colour terms was effectuated by the earlier research into basic colour terms. Examples of other colours include valge 'white', hall 'grey', sinine 'blue', roheline 'green', kollane 'yellow', punane 'red' and pruun 'brown'. For dialectal equivalents to basic colour terms, e.g. ahk 'grey', haljas 'green', vahane, vahass 'yellow', ver(r)ev 'red', see Oja 2011.

Researching the colour terms of Taani hindamisraamat (Latin Liber Census Daniae, Danish Kong Valdemars Jordebog), a 13th century manuscript of various content including 
settlement and agrarian records, Sutrop (2011: 83) suggests that there are more colours associated with place names than must 'black' and hall 'grey'. Besides the previously studied terms associated with black, e.g. Mustcen, Mustuth and grey, e.g. ? Halela, Haleloe; Halenhabus, Sutrop (2011: 85) proposes Guldan, Kuldenkava and Kullawa in conjunction with kuld 'gold', kuldne 'golden'. Raudanal, Rauculeppi, Raulceucrce are also connected to metal - raud 'ferrum'. While Mustuth designated black cattle, the kir-i place names, e.g. Kiriawold, Kiriolloe moec, Kiriucer designate variegated cattle $(<k i r j u$ 'varicoloured; diverse'). Lepat, Lippanal, Raikloep are derived from a tree name, lepp (Alnus), which marks the colour of red, also the colour of blood. In the case of Reppel, Repel and Ocrielce, Sutrop (2011: 87) agrees with Lennart Meri, who suggested that these place names are derived from the colour term rebu 'yolk; fox' with Ocrila a Middle Latin translation of rebu. (Sutrop 2011: 85-87)

Carole Hough's research on the Old English colour terms in place names could also be considered a strong impetus. Hough's (2008: 192) Old English (recorded by c. 1100) examples of blcec 'black' in place names include Blackborough (beorg 'rounded hill'), Blackbourn, Blackburn (burna 'stream'), Blagdon (dūn 'hill'), Blakenhall (halh 'nook of land'), Black Pan (penn 'enclosure (for animals)'), Blackwell (wella 'spring, stream'). Grouping together the place names by the generic element shows that beorg 'rounded hill' could be described as blaec 'black', fealu 'yellowish, fallow', grēne 'green' or moele 'variegated', that clif 'cliff' could be hwit 'white' or rēad 'red', that valleys doel and denu were always grēne 'green' or graeg 'grey', hār 'grey, hoar' and that the only colour adjective applied to churches (cirice) was hwit 'white' (Hough 2008: 184, 195-196).

This article, focusing on the colour attribute 'black', is a part of ongoing research into colour terms in Estonian place names. By utilizing the works of Marja Kallasmaa, Evar Saar, Eero Kiviniemi, Valdek Pall and Peeter Päll a base of reference for colour attributes in place names was created. A comparative analysis of must 'black' and valge 'white' attributes is planned in the future. 


\section{Method and materials}

The general archive Eesti murrete ja soome-ugri keelte arhiiv (EMSUKA) 'Archive of Estonian dialects and FinnoUgric languages' contains a place names card index. The place names card index kohanimekartoteek ${ }^{l}$ of the Institute of the Estonian Language was searched for place names beginning with (or containing) must 'black'. It consists of several collections. According to the overall statistics, there are 530,867 name cards. The collection of place names started in the 1920s, but the main part of the index was collected after World War II by the researchers of the Institute of the Estonian Language, formerly Institute of the Estonian Language and Literature. It also contains some earlier notes gathered by the researchers of the Estonian Mother Tongue Society. There are several additional collections, e.g. a collection gathered by the dialectal correspondents of the Estonian Mother Tongue Society, and Endel Varep's and Gustav Vilbaste's personal collections. Place names card index is in the process of digitalization and most of the main index's slips have been scanned; however, the digital version is not yet available or searchable on the Internet. [Eesti Keele Instituudi] kohanimeandmebaas (KNAB) 'place names database' compiled by Peeter Päll is available on the Internet. It includes, among others, 43,916 named features (111,203 names) of Estonian place names.

Place names card index itself is divided into church parish sections. Kihelkonnad 'church parishes' are historical territorial units that were in wide use until the 1920s. Even nowadays, most people know what parish they would belong to. The traditional abbreviations of church parishes used in Estonian linguistics, ethnography and elsewhere consist of three letters, e.g. Jõe $=$ Jõelähtme parish, and Noa $=$ Noarootsi parish (KNAB). For the list of Estonian Lutheran church parishes, see the abbreviations section.

1 Unless indicated otherwise all place name examples are from kohanimekartoteek 'place names card index', which is part of the eesti murrete ja soome-ugri keelte arhiiv (EMSUKA) 'Archive of Estonian dialects and Finno-Ugric languages' 
In place names card index, 1377 slips beginning with (or containing) must 'black' were found. To avoid duplication, multiple slips with the same notation in one church parish were counted as one place name. For example, there were 11 slips for Must kivi 'Black stone' in Kuusalu (Kuu) parish, but these 11 slips were counted as one place name for this particular parish. Discounting within-parish duplicate slips, there were 1081 place names. Altogether, there were 728 different place name variants beginning with (or containing) must 'black'.

\section{Most common adjectival and colour attributes in place names}

Eero Kiviniemi (1990: 150), commenting on Finnish adjectival attributes in place names, claims that there are few very general adjectives. The first five adjectival determinants express the opposition of big-small, i.e. iso and suuri for big, pieni, pikku and $v \ddot{a} h \ddot{a}$ for small, covering about $40 \%$ of the general adjectival determinants. These are followed by pitkä 'long', vanha 'old', uusi 'new' and musta 'black'. Kiviniemi (1990: 151) speculates that the characteristic of big is more general because it does not necessarily have an opposition of small. The same principle is applicable to black. There are many natural objects which can be termed black in place names, but not as many objects of the same type which can be named the opposite: white. Kiviniemi (1990: 152) and Huldén (1989: 169-175) concur that black is much more general than white. The ratio of the black-white adjectives is the same in Finnish, Finnish Swedish and Scandinavian place names, which according to Huldén is about 3:1.

In Läänemurde loodus- ja viljelusnimed 'Names of natural and cultivation objects in the western dialect area', Marja Kallasmaa (2003: 61) lists the adjectival attributes by frequency and the ratio of combinations as follows: suur 'big' (175:46), pikk 'long' (58:28), must 'black' (45:17), uus 'new' (40:16), and lai 'wide' $(35: 20)$. Must 'black' (frequency $=45$ ) is the most common colour attribute amongst natural and cultivation names in the western 
dialect area of Estonia (Kallasmaa 2003: 63). It is followed by punane 'red' (20) and valge 'white' (19) (Kallasmaa 2003: 6364). According to Evar Saar (2008: 107), must 'black' (47) is also the most frequent colour attribute in Vorru county, which historically included the parishes of Hargla, Kanepi, Karula, Põlva, Rõuge, Räpina, Urvaste and Vastseliina. It is followed by kuld 'gold' (34), valgõ 'white' (dialect variant) (27), hall, hahk (the latter is a dialect variant) 'grey' (18), and verrev (dialect variant; usually written as verev) '(blood) red' (16) (Saar 2008: 107). For more on colour terms in Estonian dialects, see Oja 1997, 2011. While black is usually the most frequent colour attribute in place names, white may not always be the second most frequent term.

\section{The usage of must 'black' in place name structures}

In Estonian, the generic term or determinant is in nominative case and usually retains the direct meaning, e.g. Mustjoggi 'Black-river'. "False" determinants are often in genitive case, e.g. Mustjõe (küla) 'Black-river (village)', whereas the real determinant is often missing or implied. In elliptical place names, there is no determinant, e.g. Musta 'Black (gen)' (Pajusalu et al. 2009: 260).

Kallasmaa (2003: 124-125) describes the most popular case structures as follows (examples are replaced with place names beginning with must 'black'):

1) $\mathrm{K}_{1}$ gen sg $+\mathrm{K}_{2}$ nom sg Mustajõgi < must 'black' + jõgi 'river'

2) $\mathrm{K}_{1}$ gen $\mathrm{pl}+\mathrm{K}_{2}$ nom sg Mustade < must 'black' + soo soo 'swamp, bog'

3) $\mathrm{K}_{1}$ gen sg $+\mathrm{K}_{2}$ gen sg Mustajõe < must 'black' + jõgi 'river'

4) $\mathrm{K}_{1}$ nom sg $+\mathrm{K}_{2}$ nom sg Mustjõgi < must 'black' + jõgi 'river'

The last pattern is the most characteristic of names with an adjectival attribute (Kallasmaa 2003: 125). Based on the literature, Saar (2008: 22) suggests that part of the name can 
syntactically-semantically express either a) a type of place, e.g. Must/jõgi 'Black/river'; b) name of a place, e.g. Mustajõe (talu) 'Black-river (farm)', where the lexical elements must 'black' and jõgi 'river' have no independent semantic meaning concerning the farm as an object of naming; or c) a specific character, which differentiates the name from others of the same type, e.g. Mustal jõe. Musta is the attribute.

\subsection{Must 'black' in nominative}

In Table 1, place names with must 'black' in nominative singular are given as ranked by frequency $(\mathrm{F})$. Where both solid and separate writing of the name exist they are counted as one place name, where possible. In nominative, for example, the six most frequent terms have both solid and separate forms: Mustjõgi Must jõgi 'Black-river' $(\mathrm{F}=26)$, Mustjärv Must järv Must Jarw 'Black-lake' (22), Mustkivi Must kivi 'Black-stone' (21), Mustoja $\sim$ Mustoya $\sim$ Must oja $\sim$ Must Oya 'Black-rivulet' (18), and Mustmägi Must mägi ${ }^{2}$ 'Black-hill' (16). The forms of Mustmets $\sim$ Must mets $\sim$ Must metz 'Black-forest' (8) and Mustkuusik Must kuusik 'Black-grove of spruce' (4) also have both forms. Mustoja talu 'Black-rivulet farm' (7) places seventh. Usually in farm names, the attribute and the determinant are both in genitive, e.g. Mustaoja talu.

Taken as is, Mustjärv 'Black-lake' (19) is the most common, followed by Mustjõgi 'Black-river' (18) and Mustoja Mustoya 'Black-rivulet' (15). Evar Saar (2008: 107) also claims that Mustjärv 'Black lake' (12) is the most frequent place name with the attribute must in Võru county. He also gives Mustsaar $\sim$ Mustassaar 'Black island' (9) as a common example of the attribute black. While in most cases Mustsaar $\sim$ Mustassaar are

2 By geographical definition, there are no mountains in Estonia. Even the highest, Suur Munamägi 'Big Egg-mountain' (318 meters), can only be considered a hill. In place names, some determinants, e.g. mägi 'hill', org 'valley' and meri 'sea', are often used to designate a relative or comparative scale. 
counted as one, here the notations are given separate frequencies.

Table 1. The attribute must 'black' in nominative as ranked by frequency $(\mathrm{F})$.

\begin{tabular}{|c|c|c|}
\hline Place name & Gloss & $\mathbf{F}$ \\
\hline $\begin{array}{l}\text { Mustjõgi (18) } \\
\text { Must jõgi (8) }\end{array}$ & Black-river & 26 \\
\hline $\begin{array}{l}\text { Mustjärv (19) } \\
\text { Must järv (2) } \\
\text { Must Jarw (1) }\end{array}$ & Black-lake & 22 \\
\hline $\begin{array}{l}\text { Must kivi (15) } \\
\text { Mustkivi (6) }\end{array}$ & Black-stone & 21 \\
\hline $\begin{array}{l}\text { Mustoja }(14) \\
\text { Mustoya }(1) \\
\text { Must oja }(2) \\
\text { Must Oya (1) } \\
\end{array}$ & Black-rivulet & 18 \\
\hline \begin{tabular}{|l|} 
Mustmägi (10) \\
Must mägi (6)
\end{tabular} & Black-hill & 16 \\
\hline $\begin{array}{l}\text { Mustmets (5) } \\
\text { Must mets (2) } \\
\text { Must metz (1) }\end{array}$ & Black-forest & 8 \\
\hline Mustoja talu & Black-rivulet farm & 7 \\
\hline Mustsaare & Black island & 4 \\
\hline \begin{tabular}{|l|} 
Mustsoo (3) \\
Mustsoot (1) \\
\end{tabular} & Black-swamp, bog & 4 \\
\hline $\begin{array}{l}\text { Mustvee (2) } \\
\text { Mustwet (1) } \\
\text { Mustweddist (1) }\end{array}$ & Black-water & 4 \\
\hline $\begin{array}{l}\text { Mustkuusik (2) } \\
\text { Must kuusik (2) }\end{array}$ & Black-grove of spruce & 4 \\
\hline Must niit & Black meadow & 3 \\
\hline Must org & Black valley & 3 \\
\hline Musthaud & Black-grave & 3 \\
\hline Mustjõe & Black-river & 3 \\
\hline Mustjõe talu & Black-river farm & 3 \\
\hline Mustkivi talu & Black-stone farm & 3 \\
\hline Mustsaare talu & Black-island farm & 3 \\
\hline
\end{tabular}




\begin{tabular}{|l|l|c|}
\hline Place name & Gloss & F \\
\hline Mustjõe küla $\sim$ Mustjoggi & Black-river village & 3 \\
\hline Must allikas $\sim$ Must alikas & Black spring & 2 \\
\hline Must Jaala järv & Black-'small (cat)boat' lake & 2 \\
\hline $\begin{array}{l}\text { Must K/kass } \\
{[\text { korts, heinamaa] }}\end{array}$ & $\begin{array}{l}\text { Black C/cat } \\
{[\text { barrelhouse, hayfield] }]}\end{array}$ & 2 \\
\hline Must kirp & Black flea & 2 \\
\hline Must lomp & Black puddle & 2 \\
\hline Must meri & Black sea & 2 \\
\hline Must nasu & $\begin{array}{l}\text { Black 'small grass islet' } \\
\text { (dialect) }\end{array}$ & 2 \\
\hline Must plats & Black place, site & 2 \\
\hline Must rahu & $\begin{array}{l}\text { Black 'small stone-filled islet' } \\
\text { (dialect) }\end{array}$ & 2 \\
\hline Must sild & Black bridge & 2 \\
\hline Mustjõe mõis & Black-river manor & 2 \\
\hline Mustjõe oja & Black-river rivulet & 2 \\
\hline Mustjärve talu & Black-lake farm & 2 \\
\hline Mustkraav & Black-ditch & 2 \\
\hline Mustküla & Black-village & 2 \\
\hline Must-oit & Black-'puddle' (dialect) & 2 \\
\hline Mustoja küla & Black-rivulet village & 2 \\
\hline Mustsaar & Black-island & 2 \\
\hline
\end{tabular}

The most common place names beginning with must 'black' are names of natural objects, e.g. jogi 'river', järv 'lake', kivi 'stone', oja 'rivulet', mägi 'hill', mets 'forest', not settlement names, e.g. talu 'farm'. Some words are only used dialectally; these are either very specific or fairly uncommon, e.g. jaala 'small (cat)boat', nasu 'small grass islet', rahu 'small stone-filled islet', and oit 'puddle'. Jaala in Must Jaala järv 'Black Jaala lake' might be indicative of a special type of small (cat)boat (EKSS). While jalg, jala 'foot' carries a different meaning, in Jõhvi (Jõh) parish Must Jaala järv and Must-Jala järv have been recorded alternatively. Rebassoo (1972: 14) describes nasv (also nasu, näsu; near Pärnu rava) as a low-standing and small grass islet covered with halophilic plants typical of coastal meadows. During high-water times, nasvad (pl) are usually covered with 
water. Kallasmaa (1996: 224) suggests nasu, nasva 'small peninsula, reef, stony shallow-water place in the sea' for Mustnasu (Pöi). The same declension is mostly used in insular and western Estonian dialects (VMS), but nasv, nasva designates a 'stony shallow-water place in the sea' (EKSS). Rahu is a western Estonian expression for a small islet (less than a few hectares), which is usually filled with scree, boulders and sparse vegetation. It is possible for windblown water to flood most of these islets. The names of rahud (pl) and kared (pl) - very similar, but even smaller islets - were established when they were still mostly under water (Rebassoo 1972: 14). The dialectal oit 'puddle, pond, a hole full of water' (EKSS) is synonymous with lomp. In Simuna, both oit and oik are noted, and in Koeru only oik (VMS s.v. oik, oit) is noted. Must-oit (Kod, MMg) and Mustoit (Kod) are examples of place names.

With the attribute must in nominative, the incidence of the determinant talu 'farm' is low, because the most common farm name template is a one-part name in genitive, e.g. Musta. The generic term, e.g. talu 'farm', is usually only added in naming or counting, not in speaking of place names (Saar 2008: 69). Considering all the place names with must 'black' in them, the generic term talu 'farm' has a much higher frequency than in nominative only. Table 2 accounts for other place names where must 'black' is not in nominative case.

\subsection{Must- 'black' not in nominative}

Some of the place names beginning with (or containing) must 'black' do not have a direct connection to the colour attribute black. For example, in farm names the connection to black can be more indirect. Pall (1969:145) remarks that in some North Tartu revision records Musta and Musti appear interchangeably. Must 'Black' was also used as a family name. As to the relationship between Musta $\sim$ Musto $\sim$ Musti, it should be noted that Musto originates from the oi-diminutive, while the form Musti might be a case of the later $i$-diminutive. In Saare- 
maa kohanimed I 'Place names of Saaremaa [island] I', Kallasmaa (1996: 223) suggests that Musta (farm) in Jämaja is a derivation from a proper name. In place names, Musto is rare; in this study, it appears in conjunction with forest, as in Musto mets (Kse) and lea in Mustonurm (Võn). Saar (2008: 144) claims that even without knowing the actual motives of naming, some place name attributes, e.g. Musti, cannot be considered anything but archaic personal names or a person's cognomen. The $i$-stem vowel marks it as a personal name. It should be noted that Musti is also a name commonly given to animals of dark colouring, e.g. dogs. The most frequent determinant with Must/i is Musti talu 'farm' (11), followed by Mustimägi (2) Musti mägi 'hill' (4), Mustimets $\sim$ Musti mets 'forest' (2), and Mustinurm $\sim$ Musti y nuem 'lea' (Rõn). Mustivere (Vil) also appears. In some cases Musti is paired with personal names, e.g. Musti Jürri, Musti Michel (Vilbaste Jõe), and Musti-Aabel, Musti Juhkami talu 'farm' (Plv). An elliptical Musti (Vilbaste Jõe) is also recorded.

Muste/e (15): Mustekivi 'stone' (Hag, VNg), Mustekivi mägi 'stone hill'(Hag), Mustemäe talu 'hill farm' (Hag), Mustemägi 'hill' (Hag), Mustetoa talu 'room farm' (Hag); Mustelepa väli 'alder field' (Kei), Mustelepavälja mägi 'alder-field hill' (Kei); Mustepaju talu 'willow farm' (Koe), Mustekännu mets 'stump forest' (Kos), Mustelõugu heinamaa 'hole, pit' hayfield' (Kul), Mustemetsa talu 'forest farm'(Kul); and Mustepere talu 'family farm' (Rap).

Must/u (13): Mustu talu 'farm' (Mär, Rid), küla 'village' (Nis), mets 'forest' (San), metsavahikoht 'gamekeeper's place' (Var), mägi 'hill' (Urv), and oja 'rivulet' (Rap). Also, Mustumetsa talu 'forest farm' (Hel, San) Mustumõtsa 'forest' (San), Mustumõtsa talu 'forest farm' (Hlm); Mustualune heinamaa 'below hayfield' (Mih), Mustuaru pere 'dryland' family' (Mih). Must/ukse heinamaa 'hayfield', talu 'farm' (Krk), and Must/ukse lomp 'puddle' (Kar).

Must/o (2): Musto mets 'forest' (Kse), Mustonurm 'lea' (Võn). 
Table 2. The non-nominative must 'black' by frequency $(\mathrm{F})$.

\begin{tabular}{|c|c|c|}
\hline Place name & Gloss & $\mathbf{F}$ \\
\hline Musta talu & Black farm & 22 \\
\hline Musti talu & Musti farm & 11 \\
\hline Mustametsa talu & Black-forest farm & 9 \\
\hline Mustassaar & Black-island $^{3}$ & 9 \\
\hline Mustassaare talu & Black-island farm & 9 \\
\hline $\begin{array}{l}\text { Mustakivi } \\
\text { Mustakiwi }\end{array}$ & Black-stone & 7 \\
\hline Mustasaare talu & Black-island farm & 7 \\
\hline $\begin{array}{l}\text { Musti mägi } \\
\text { Mustimägi }\end{array}$ & Musti hill & 7 \\
\hline Musta & Black & 6 \\
\hline Mustakivi talu & Black-stone farm & 6 \\
\hline Mustajõe talu & Black-river farm & 5 \\
\hline Mustamäe talu & Black-hill farm & 5 \\
\hline Mustaoja & Black-rivulet & 5 \\
\hline Mustaoja talu & Black-rivulet farm & 5 \\
\hline Mustarahu & $\begin{array}{l}\text { Black-'small stone-filled islet' } \\
\text { (dialect) }\end{array}$ & 5 \\
\hline Mustla küla & Mustla village & 5 \\
\hline Mustaaugu talu & Black-hole, pit farm & 4 \\
\hline $\begin{array}{l}\text { Mustakivi põld } \\
\text { Mustakivi põllud }\end{array}$ & Black-stone field(s) & 4 \\
\hline Mustamäe & Black-hill & 4 \\
\hline Mustla & Mustla & 4 \\
\hline
\end{tabular}

With the non-nominative must 'black' the determinant talu 'farm' is most common (see Table 2), e.g. Musta talu 'Black farm' (22), Musti talu 'Musti farm' (11), Mustametsa talu 'Black-forest farm' (9), Mustassaare talu 'Black-island farm' (9), Mustasaare talu 'Black-stone farm' (6), Mustajõe talu 'Black-river farm' (5), Mustamäe talu 'Black-hill farm'

3 Literally Mustassaar 'Black island' designates an island or an islet (Lgn, Rid), but in most cases it is not an actual island, but rather a farm (Jmd, $\mathrm{KJn}$, Pee), forest or a forest island (Iis, Pee, VNg), hayfield (Sim) or an island in a bog or marsh (Kod, Kos). 
(5), Mustaoja talu 'Black-rivulet farm' (5), Mustaaugu talu 'Black-hole, pit farm' (4).

The following place names with must 'black' in non-nominative were also frequent Mustassaar 'Black-island' (9) (without the determinant talu 'farm'), Mustakivi Mustakiwi 'Black-stone' (7), Musti mägi Mustimägi 'Musti hill' (7), Mustaoja 'Blackrivulet' (without the determinant talu 'farm'), dialectal Mustarahu 'Black-'small stone-filled islet'” (5), Mustamäe 'Black-hill' (4). Mustla küla 'Mustla farm' (5) and Mustla 'Mustla' (4) were also found. The determinant põld (sg), põllud (pl) appeared in Mustakivi põld Mustakivi põllud 'Black-stone field(s)' (4). The elliptical Musta 'Black' was found in six instances.

Some derivations carry a tenuous association with, or are simply too far removed from, the colour attribute, e.g. mustlane, mustlase 'gypsy' and mustikas, mustika 'blueberry, bilberry'. Examples from Table 2 include the following place names Mustika talu 'Blueberry farm' (10), Mustlase mägi Mustlasemägi 'Gypsy-hill' (9), Mustika mägi Mustikamägi 'Blueberry-hill' (8), Mustiksoo Mustiksuo Mustikuo 'Blueberry-swamp, bog' (8), Mustika 'Blueberry' (4), Mustiku talu 'Black cow farm' (4), Mustlasesoo $\sim$ Mustlase soo $\sim$ Mustlasesuu 'Gypsy-swamp, bog' (4). The suffix -lane produces a person's national or ethnic affiliation from a place name, e.g. Eesti 'Estonia' < eest/lane 'Estonian' (EKK s.v. SM 22), and must $<$ must/lane 'gypsy'. In mustikas 'blueberry', the suffix -kas acts as a neutral suffix carrying over the characteristics from the underlying stem. Valdek Pall (1977: 142) suggests that derived terms from the proper name level are also toponyms, for which a match has been found from animal names, e.g. ? Mustiku (Kallasmaa 2000: 146). For mustu, Mägiste (1928: 12, 39, 183) claims that $-o i$ (Vepsian) $>-o$ (Finnish) $>-u$ (Estonian) is a consistent phonetic rule in northern, central and south-western Estonian dialect areas. He suggests (1928: 44) that, when the $o i$-diminutive is present in animal names, it is also present in proper names for those animals. Mägiste categorises musto $i$ (1928: 12, 44) as an animal name either for: 1) a cow, e.g. Seäl ma murtsin mustu sarved 'There I broke the horns of mustu' 
(in Setu folk song); 2) a (dark-skinned) seal (Jäm, Khk, Mus, $\mathrm{Krj}, \mathrm{Khn}$ ), which is colloquially used for a ringed seal (VMS, EKSS s.v. mustu), e.g. mustu; or 3) an ox, e.g. must/u, must/o. In the case of Mustuth, Sutrop (2011: 83, 87) suggests the original meaning of black cattle. Mägiste (1928: 222) proposes that all Baltic-Finnic animal names are derived from colour names or names of the days, and that others could be reduced to the adjectival meaning. Mustuke(ne), mustukese is colloquially used for a dark-skinned (tumedavereline 'dark-blooded'), swarthy person (or animal). Mustlase talu 'Gypsy farm' (2) also appears in place names card index. Grammatically, the declension mustik, mustiku is used for the 'black cow' meaning (EKSS), e.g. Mustiku talu 'Black cow farm' (4). Mustikas, mustika is used for the 'blueberry' meaning (EKSS), e.g. Mustika talu 'Blueberry farm' (10). The shortened form mustik- sometimes designates blueberry, e.g. Mustikaru talu 'Blueberry-'dryland' farm' (2).

The dialectological dictionary offers examples from many parishes where one can disregard the meaning of 'black cow' for mustik since it clearly designates the shortened blueberry meaning (VMS s.v. mustik). The suffix -ik by itself is a non-productive adjectival suffix, e.g. metsik 'wild', lapsik 'childish', and lapik 'oblate' (EKK s.v. SM 33).

Saar (2008: 128; 130-131) classifies mustikas 'blueberry' (7) as an attribute of a (wild) plant name. He concentrates on maasi/kas 'strawberry', which is the most frequent (26) name of a berry (plant attribute) in Võru county place names. Saar considers Maasikaorg 'strawberry-valley' (Urv Antsla) to be a secondary name from the farm name Maasika 'strawberry' (gen), which itself has been repeatedly based on a personal name. Although Saar incorporates Maasikmägi Maasikamägi 'strawberry-hill' (13), in Table 2 mustika 'blueberry' (gen sg) and mustik 'blueberry; black cow' are counted separately.

The verb mustu/ma 'go or turn black (as of colouring or become dirtied)' is used in Torma, Kolga-Jaani, Tarvastu, Rannu, Puhja, Karula, Põlva and Vastseliina counties, e.g. Õhtu pimeneb, metsamüür mustub 'The evening darkens, the wall of forest blackens' (EKSS, VMS). The dialectal mustutama is syno- 
nymous with määrima 'to dirty, to make dingy' (VMS). Mustama, mustata denotes: 1) mustendama - (being) of a black colour, when something seems to be either black or dark, blacken(ed), e.g. Värskelt küntud muld mustas 'The freshly ploughed soil blackened'; an abundance of something or somebody; 2) (make) dirty, unclean; or 3) slander, revile (EKSS s.v. mustama, mustendama). For stative colour verbs and their situation structures, see Paulsen in this volume.

The place name Mustla consists of must 'black' and the suffix $-l a$. $-l a(-l \ddot{a})$ is an old suffix which was used to denote a place or was used as a diminutive. In common vocabulary, it has been restrictedly revived, now usually used for either buildings, e.g. suvila 'summerhouse' < suvi 'summer', or an area of land, e.g. põhjala 'Norse, northern land' < põhi, põhja (gen) 'north' (EKK SM 21, Pajusalu et al. 2009: 270). In place names, it is commonly used all over Estonia, but especially in northern Estonia and on Saaremaa island, as well as in Võru county's Urvaste and Rõuge parishes in southern Estonia (for a map of $l a$-suffices see Pajusalu et al. 2009: 282). Some of today's lasuffixes have belonged to another type (Pajusalu et al. 2009: 270-271): 'jala 'foot'; -küla 'village'; -laid 'islet'; -valla 'county'; -vilja 'fruit, drupelet', and -välja 'field'. Gustav Vilbaste's archive notes (mostly from 1933) reveal several other variations, e.g. Mustalla, Mustell, Mustee, Mustlatz, Musten and Mustaon. Kettunen (1955) surmises that in Finnish place names the lasuffix has mostly been joined with personal names. Such examples are abundant in Finnish.

\subsection{Determinants in combination with must- attribute}

Overall, 219 different determinants or post-components were found in place names card index. The most frequent determinant was talu 'farm' (231), which covered about $21 \%$ of all determinants. The following determinants (see Figure 1) were far less frequent: mägi 'hill' (70), mets 'forest' (45), heinamaa 
'hayfield' (43), küla 'village' (40), jõgi 'river' (39), soo 'swamp, bog' (36), kivi 'stone' (31), oja 'rivulet' (31), järv 'lake' (28), saun 'sauna' (19), saar (17) 'island, islet' (may also signify a forest, a forest island, a bog or a hayfield, see footnote 2 for further explanations), org 'valley' (15), and tee 'road' (14). In Figure 1, $[\mathrm{x}]$ marks elliptical place names.

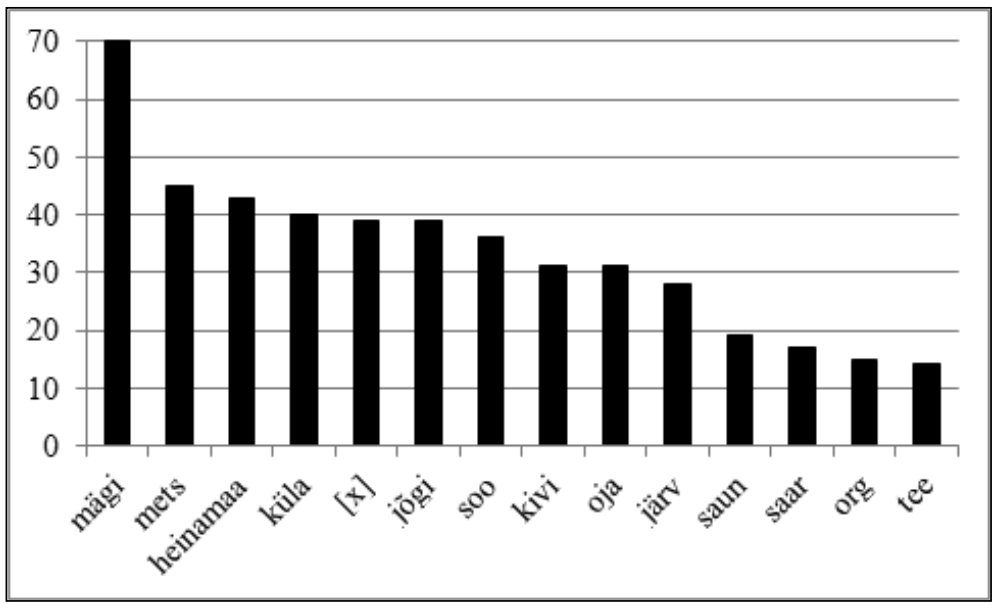

Figure 1. Most frequent determinants after must 'black' (excluding talu 'farm').

Apparently, the most common is the attribute + determinant combination. The most straightforward combinations are with järv 'lake', e.g. Mustjärv Must järv Must Jarw (the frequency of this combination 22 / the overall frequency of this determinant 28, 78.6\%); kivi 'stone', e.g. Must kivi $\sim$ Mustkivi (31/21, 67.7\%); with jõgi 'river', e.g. Mustjõgi Must jõgi (26/39, 66.7\%); oja 'rivulet', e.g. Mustoja Must oja (16/31, 51.6\%); mägi 'hill', e.g. Mustmägi (10) Must mägi (6) (16/70, 22.9\%); mets 'forest', e.g. Mustmets Must mets $(7 / 45,15.6 \%)$. There are some interesting combinations not in nominative case, e.g. Mustassaar 'Black-island' (9/17, 52.9\%), Mustla küla 'village' (5/40, 12.5\%), Musta talu 'farm' (22/231, 9.5\%), and Mustakännu Mustakannu heinamaa 'Black-stump hayfield' (4/43, 9.3\%). 
Some determinants are more common in combination with the genitive mustik(a) and mustlase, e.g. Mustlase org $\sim$ Mustlaseorg 'Gypsy-hill' (6/15, 40.0\%), Mustiksoo Mustiksuo 'Blueberry-swamp, bog' $(6 / 36,16.7 \%)$ and Mustlase saun 'Gypsy sauna' $(3 / 19,15.8 \%)$. Musta $(5 / 39,12.8 \%)$ was the most frequent elliptical place name. There were 14 instances of tee 'road' determinants, but they all occurred only once.

Some of the most frequent determinants in conjunction with must- are presented in the following paragraphs.

Talu 'farm' (119): The most frequent (see Table 3) were Musta (22), Musti (11) and Mustika 'blueberry' (10). These were followed by two-part names, usually with either one or both of the attributes in the genitive case, e.g. Mustametsa talu 'Black-forest farm' (9), Mustassaare talu 'Black-island farm' (9), Mustasaare talu 'Black-island farm' (7), Mustoja talu 'Blackrivulet farm' (7), Mustakivi talu 'Black-stone farm' (6), Mustajõe talu 'Black-river farm' (5), Mustamäe talu 'Black-hill farm' (5), and Mustaoja talu 'Black-rivulet farm' (5).

Table 3. Talu 'farm' determinants (occurring more than once) by frequency $(\mathrm{F})$.

\begin{tabular}{|l|l|c|}
\hline Term & Gloss & F \\
\hline Musta talu & Black farm & 22 \\
\hline Musti talu & Musti farm & 11 \\
\hline Mustametsa talu & Black-forest farm & 9 \\
\hline Mustassaare talu & Black-island farm & 9 \\
\hline Mustasaare talu & Black-island farm & 7 \\
\hline Mustoja talu & Black-rivulet farm & 7 \\
\hline Mustakivi talu & Black-stone farm & 6 \\
\hline Mustajõe talu & Black-river farm & 5 \\
\hline Mustamäe talu & Black-hill farm & 5 \\
\hline Mustaoja talu & Black-rivulet farm & 5 \\
\hline Mustaaugu talu & Black-hole, pit farm & 4 \\
\hline Mustajärve talu & Black-lake farm & 3 \\
\hline Mustjõe talu & Black-river farm & 3 \\
\hline Mustkivi talu & Black-stone farm & 3 \\
\hline Mustsaare talu & Black-island farm & 3 \\
\hline
\end{tabular}




\begin{tabular}{|l|l|c|}
\hline Term & Gloss & F \\
\hline Mustaantsu talu & Black-Ants farm & 2 \\
\hline Mustanómme talu & Black-heath farm & 2 \\
\hline Mustaru ${ }^{4}$ talu & $\begin{array}{l}\text { Black-'dry land' farm } \\
\text { (dialect) }\end{array}$ & 2 \\
\hline Mustassare talu & Black-island farm & 2 \\
\hline Mustatoa talu & Black-room farm & 2 \\
\hline Mustaugu talu & Black-hole, pit farm & 2 \\
\hline Musteni talu & Musteni farm & 2 \\
\hline Mustjärve talu & Black-lake farm & 2 \\
\hline Mustoneni talu & Mustoneni farm & 2 \\
\hline Mustu talu & Mustu farm & 2 \\
\hline Mustumetsa talu & Mustu-forest farm & 2 \\
\hline
\end{tabular}

Mägi, genitive mäe 'hill' (70): Mustmägi (10) Must mägi (6) is followed by several place names containing derivational suffices with mustlane 'gypsy' (11), e.g. Mustlase mägi (6) Mustlasemägi (3), Mustlasmägi (1), Mustlaste mägi (pl) (1) or mustikas 'blueberry', e.g. Mustika mägi (4) Mustikamägi (4) and Musti mägi (4).

Table 4. Mägi 'hill' determinants (occurring more than once) by frequency (F).

\begin{tabular}{|l|l|c|}
\hline Term & Gloss & F \\
\hline $\begin{array}{l}\text { Mustmägi (10) } \\
\text { Must mägi (6) }\end{array}$ & Black-hill & 16 \\
\hline $\begin{array}{l}\text { Musti mägi (5) } \\
\text { Mustimägi (2) }\end{array}$ & Musti-hill & 7 \\
\hline Mustamäe mägi & Black-hill hill & 3 \\
\hline Mustakivi mägi & Black-stone hill & 2 \\
\hline Mustamägi & Black-hill & 2 \\
\hline
\end{tabular}

Mets, genitive metsa 'forest' (45): A simple combination is frequent, and the most common is Mustmets (5) Must mets (2), followed by several musta (gen) place names, e.g. Mustamets (3),

4 Mustaru < must 'black' + aru ?'dry land' (VMS s.v. aru) 
Mustasaare mets 'Black-island forest' (3), and Mustaoja mets 'Black-rivulet forest' (2). Metsa (gen) is seen in Mustametsa (Kuu), dialectally Mustumõtsa (San). The far-fetched Mustika mets (2) Mustikamets 'blueberry-forest' (1) and Mustlase mets (2) Mustlasemets 'Gypsy-forest' (1) also occur.

Table 5. Mets 'forest' determinants (occurring more than once) by frequency $(\mathrm{F})$.

\begin{tabular}{|l|l|c|}
\hline Term & Gloss & F \\
\hline $\begin{array}{l}\text { Mustmets (5) } \\
\text { Must mets (2) }\end{array}$ & Black-forest & 7 \\
\hline Mustamets & Black-forest & 3 \\
\hline Mustasaare mets & Black-island forest & 3 \\
\hline Mustaoja mets & Black-rivulet forest & 2 \\
\hline $\begin{array}{l}\text { Mustimets } \\
\text { Musti mets }\end{array}$ & Musti-forest & 2 \\
\hline
\end{tabular}

Heinamaa 'hayfield' (43), also heinamaad (pl) (3), aynamaa (1): Occurring more than once are Mustakännu (2) Mustakannu (2) heinamaa 'Black-stump hayfield' (4) and Mustajõe heinamaa 'Black-river hayfield'. Several dialect components appear between the attribute must(a) and the determinant heinamaa, e.g. läte, lätte 'spring', pali '?', peakse? pööksu 'swamp-islet, small weald, poscage', lõugu 'small bay; here (water)hole or a pit', and saadu 'separate piece of arable land (in a two-field system)'.

In Mustalätte heinamaa (Ote), a well-known synonym for allikas 'spring' is used - läte, lätte 'spring, well' (EKSS). Lätlik $<$ läte has been noted in Otepää parish (VMS). Although pali has several different dialect meanings in the case of Mustapali heinamaa (Trv), the meaning has not been fully certified. The most likely meaning for peakse or pööksu, as in Mustapeakse? Mustapööksu heinamaa (Phl) and Mustapeeksu selg, is pääks(es) (pääksi) 'islet in a swamp or bog, small weald, poscage' (VMS), used in western and insular dialects (Khk, Mus, Emm, Käi, Rei, Phl, Hää, Saa). Lõugas, lõugu represents a small bay or lough (EKSS s.v. lõugas II), or in the case of Mustelõugu heinamaa (Kul) possibly a (water) hole or a pit in the hayfield. Saat, saadu 
is a 'separate piece of arable land (in a two-field system)' (VMS, EKSS), e.g. Mustsaadu heinamaa (also mägi) 'hayfield (also mountain)' (Hls, Mulgi dialect) and Mustlassaadu heinamaa 'hayfield' (Saa, western dialect). In a hayfield, one might also come across saad, sao, saadu 'haycock' (EKSS).

Küla 'village' (40): Most are simple attribute + determinant combinations. Mustahamba 'ergot' < musta 'black' + ham$b a$ 'tooth' (Rõu, Vas), however, is surprising because in dialect mustahamba can also denote ergot (Claviceps), or the corn infected with it, in Rõuge (VMS).

Table 6. Küla 'village' determinants (occurring more than once) by frequency $(\mathrm{F})$.

\begin{tabular}{|l|l|c|}
\hline Term & Gloss & F \\
\hline Mustla küla & Mustla village & 5 \\
\hline $\begin{array}{l}\text { Mustküla (2) } \\
\text { Must küla (1) }\end{array}$ & Black-village & 3 \\
\hline Musta küla & Black village & 3 \\
\hline $\begin{array}{l}\text { Mustjõe küla (2) } \\
\text { Mustjoggi (1) }\end{array}$ & Black-river village & 3 \\
\hline Mustahamba küla & 'Ergot' village & 2 \\
\hline Mustametsa küla & Black-forest village & 2 \\
\hline Mustoja küla & Black-rivulet village & 2 \\
\hline
\end{tabular}

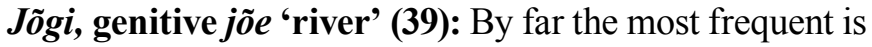
Mustjõgi (17) Must jõgi (8) Mustjõgi [oja 'rivulet'] (1) (26). It also occurs with the determinant in genitive, e.g. Mustjõe (Amb, Tln, Vai) and with both the attribute and determinant in genitive in Mustajõe (Tln); there is a possible duplicate in Mustajoe (Vai).

Soo 'swamp, bog' (36): Mustiksoo (5) Mustiksuo 'Blueberry swamp' (Kuu) (6), Mustsoo 'Black-swamp' (3), Mustikasoo 'Blueberry-swamp' (2) Mustika soo (1), Mustlasesoo (2) Mustlase soo 'Gypsy-swamp' (1), Mustasaare soo 'Black-island swamp' (2), and Mustiksoo soo (2) 'Blueberry-swamp swamp'. In many nature names, synonymous post-components stack up (Pajusalu et al. 2009: 260). In Kuusalu parish, the notation of blueberry swamp varies, e.g. Mustiksoo, Mustiksuo, and Mustik- 
soo soo. The "grammatically correct" variant of blueberryswamp would be Mustikasoo (Nõo, Vas).

Kivi 'stone' (31): Again the simple combination, i.e. Must kivi (15) Mustkivi 'Black-stone' (6), is the most common. It is followed by the genitive form Mustakivi (6) Mustakiwi (Vilbaste Jõe) (1) and Mustekivi 'Muste-stone' (3). Mustad kivid (pl) (Kuu) and Mustlasekivi 'Gypsy-stone' (SJn) also appeared in the index.

Oja 'rivulet' (31): There are a few variations on the oja 'rivulet' combination, and the top three are Mustoja (14) Must oja 'Black rivulet' (2), the genitive Mustaoja (5) and Mustjõe oja 'Black-river rivulet' (2). Additionally, there are orthographical variants Must Oya (Lai) and Mustoya (Rap).

Järv, genitive järve 'lake' (28): Mustjärv (19), Must järv (2) and Must Jarw (1) are the most common combinations. Duplicates of Mustjärv are Kantküla Mustjärv 'Kantküla's Black-lake' (VJg) and Vasavere mustjärv 'Vasavere's black-lake' (Jõh). In the case of Jõhvi, Must Jaala järv (Iis, Jõh) and Must-Jala järv (Jõh) are most probably duplicates; both designate a foot, not a specific sort of boat (jaala), although dialectally that meaning is also in use in Jõhvi, as it is a coastal area. The genitive Mustajärv (Räp) might be a duplicate of the nominative. In Põlva parish, Mustasaare järv 'Black-island lake' was noted.

Saun, genitive sauna 'sauna' (19): The most frequently used is Mustlase saun 'Gypsy sauna' (Aud, Tõs, Tür), but surprisingly enough it also occurs in Musta-Jüri saun 'Black-Jüri sauna' (Juu, PJg). Mustamäe saun 'Black-hill sauna' (Hlj, Vilbaste Jõe) occurs twice. Jüri was and still is a popular personal name.

Saar (17), saare (6), saared (1, pl), sare (1) 'island': Mustassaar (9) and Mustsaar (2) are the most frequent in nominative, and Mustsaare (4) and Mustassaare (2) in genitive. The plural occurs once in Mustasaared 'Black-islands' (Võn). Mustasare is a one-time occurrence in Urvaste (Urv). In Peetri parish, both Mustassaar and Mustsaare were noted.

Org, genitive oru 'valley' (15): Mustlase org (4) Mustlaseorg (2) 'Gypsy-valley', Must org (nom) (3) and Mustaorg (gen) (2). In Karksi parish, both the solid and separate forms of Mustlase org Mustlaseorg 'Gypsy-valley' are found. 
Tee 'road' (14): All instances occur only once, e.g. Musta tee (Vil), Mustajõe tee 'Black-river road' (Saa), Mustamäe tee 'Black-hill road' (Tln), Mustaneitsite tee 'Black-virgins road' (Pal), Mustaoja tee 'Black-rivulet road' (Se), Mustapali tee 'Black-? road' (Vil), Adra-Mustasaare tee 'Plough-black-island road' (KJn), Mustassilla tee 'Black-bridge road' (Kad), Mustjõe tee 'Black-river road' (Tln), Mustlao tee 'Black-chaff[housing] road' (dialectally ladu, lao 'part of the housing room or a separate housing where chaff was kept' [VMS s.v. lao, EKSS s.v. aganik]) (Lüg), Mustoja tee 'Black-rivulet road' (Kuu), Mustsaare tee 'Black-island road' (Lüg) and Mustvee tee 'Blackwater road' (Pal).

Elliptical (39): Most frequently Musta (5), Mustika 'blueberry' (4) and Mustla (2). There were several apparently personal names, e.g. Musta Ado (Ksi), Musta Jürgen (Vilbaste Jõe), Musta Mick (Vilbaste Jõe), Musta Siem (Vilbaste Jõe); Musti Jürri (Vilbaste Jõe), Musti Michel ? Musty Michell (Vilbaste Jõe), Musti-Aabel (Plv) and Mustwesit Marri '? Mari of Mustvee' (Trm). Some are possible family or proper name derivations, e.g. Mustis (Lei), Mustruck (Pal), and Mustura (Lei). An example of a diminutive is Musta/kese. Mustassaare 'Black-island' (KJn) is elliptical since farm is not included.

\section{Conclusion}

The data for analysis was obtained from place names card index of the Institute of the Estonian Language, which is a part of the Eesti murrete ja soome-ugri keelte arhiiv (EMSUKA) 'Archive of Estonian dialects and Finno-Ugric languages'. In the place names card index, 1377 slips beginning with or containing must 'black' were found. Discounting duplicate slips in one county, there were 1081 place names, 728 of them different. With must 'black' in nominative, the three most common place names were Mustjõgi Must jõgi 'Black river' (26), Mustjärv Must järv Must Jarw 'Black lake' (22) and Must kivi Mustkivi 'Black stone' (21). The most common non-nominative 
must 'black' in place names are Musta talu 'Black farm' (22) and Musti talu 'Musti farm' (11), followed by the far-fetched Mustika talu 'Blueberry farm' (10). The most frequent of 219 different determinants or post-components were talu 'farm' (231), mägi 'hill' (70), mets 'forest' (45), heinamaa 'hayfield' (43), küla 'village' (40), jõgi 'river' (39), soo 'swamp, bog' (36), kivi 'stone' (31), oja 'rivulet' (31), järv 'lake' (28), saun 'sauna' (19), saar 'island, islet' (17), org 'valley' (15), and tee 'road' (14).

The most common simple attribute (nom) + determinant (nom) combinations are with järv 'lake' (28, 78.6\%), kivi 'stone' (67.7\%), jõgi 'river' (66.7\%), oja 'rivulet' (51.6\%), mägi 'hill' (22.9\%) and mets 'forest' (15.6\%). There are some interesting combinations, e.g. Mustassaar 'Black island' (9/17, 52.9\%), Mustla küla 'village' (5/40, 12.5\%), Musta talu 'farm' (22/231, 9.5\%), and Mustakännu Mustakannu heinamaa 'Black-stump hayfield' (4/43, 9.3\%). Some determinants are more common in combination with the genitive mustik(a) 'blueberry' and mustlase 'gypsy', e.g. Mustlase org Mustlaseorg 'Gypsy valley' (6/15, 40.0\%), Mustiksoo Mustiksuo 'Blueberry swamp, bog' (6/36, 16.7\%) and Mustlase saun 'Gypsy sauna' (3/19, 15.8\%). Musta $(5 / 39,12.8 \%)$ was the most frequent elliptical place name.

This research would greatly benefit from a comparison with the attribute valge 'white'. The combined analysis of the attributes must-valge 'black-white' is ongoing and not yet complete. Furthermore, a general overview of the colour attributes, e.g. puna(ne) 'red', kolla(ne) 'yellow', rohe(line) 'green', sini(ne) 'blue' and hall 'grey' would help to complete the research on the colour attributes in Estonian place names. Whether to include hõbe 'silver', kuld, kulla 'gold' and some of the dialect colour words is yet to be determined.

\section{Acknowledgements}

The study was supported by the base funding of the Institute of the Estonian Language, Estonian Ministry of Education and Research project SF0050037s10 and the Estonian Science 
Foundation grant no 8168. This support is highly acknowledged. I would also like to thank Professor Urmas Sutrop for the opportunity to do this research, and my other colleagues Vilja Oja, Marja Kallasmaa, Mari Uusküla and Peeter Päll at the Institute of the Estonian Language for their helpful comments.

\section{Address:}

Kaidi Rätsep

Institute of the Estonian Language

Roosikrantsi 6

Tallinn 10119

Estonia

Tel.: +372 6177520

E-mail: Kaidi.Ratsep@eki.ee

\section{Abbreviations}

nom $=$ nominative case

gen $=$ genitive case

$\mathrm{sg}=$ singular

$\mathrm{pl}=$ plural

\section{Parishes (and other index sections):}

Ambla (Amb), Anna (Ann), Anseküla (Ans), Audru (Aud), Emmaste (Emm), Hageri (Hag), Haljala (Hlj), Halliste (Hls), Hanila (Han), Hargla (Har), Harju-Jaani (HJn), HarjuMadise (HMd), Helme (Hel), Häädemeeste (Hää), Iisaku (Iis), Jaani (Jaa), Juuru (Juu), Jõelähtme (Jõe), Jõhvi (Jõh), Jämaja (Jäm), Järva-Jaani (JJn), Järva-Madise (JMd), Jüri (Jür), Kaarma (Kaa), Kadrina (Kad), Kambja (Kam), Kanepi (Kan), Karja (Krj), Karksi (Krk), Karula (Krl), Karuse (Kse), Keila (Kei), Kihelkonna (Khk), Kihnu (Khn), Kirbla (Kir), Kodavere (Kod), Koeru (Koe), Kolga-Jaani (KJn), Kose (Kos), Kraasna (Kra), Kullamaa (Kul), Kursi (Ksi), Kuusalu (Kuu), Kõpu (Kõp), Käina 
(Käi), Kärla (Kär), Laiuse (Lai), Leivu (Lei), Lihula (Lih), Luke (Luk), Lutsi (Lut), Lääne-Nigula (LNg), Lüganuse (Lüg), Maarja-Magdaleena (MMg), Martna (Mar), Mihkli (Mih), Muhu (Muh), Mustjala (Mus), Märjamaa (Mär), Nissi (Nis), Noarootsi (Noa), Nõo (Nõo), Otepää (Ote), Paide (Pai), Paistu (Pst), Palamuse (Pal), Peetri (Pee), Pilistvere (Pil), Puhja (Puh), Põltsamaa (Plt), Põlva (Plv), Pärnu (Pär), Pärnu-Jaagupi (PJg), Pöide (Pöi), Püha (Pha), Pühalepa (Phl), Rakvere (Rak), Rannu (Ran), Rapla (Rap), Reigi (Rei), Ridala (Rid), Risti (Ris), Ruhnu (Ruh), Rõngu (Rõn), Rõuge (Rõu), Räpina (Räp), Saarde (Saa), Sangaste (San), Setumaa (Se), Simuna (Sim), Suure-Jaani (SJn), Tallinn (Tln), Tartu-Maarja (TMr), Tarvastu (Trv), Tori (Tor), Torma (Trm), Tõstamaa (Tõs), Türi (Tür), Urvaste (Urv), Vaivara (Vai), Valga (Val), Valjala (Vll), Varbla (Var), Vastseliina (Vas), Vigala (Vig), Viljandi (Vil), Viru-Jaagupi (VJg), Viru-Nigula (VNg), Vormsi (Vor), Võnnu (Võn), Väike-Maarja (VMr), Vändra (Vän) and Äksi (Äks). Additionally there are sections for the general (varia), Livonian (liivi) and Votic (vadja). The Vilbaste collection is marked Vilbaste.

\section{References}

EKK = Erelt, Mati, Tiiu Erelt, and Kristiina Ross (2007) Eesti keele käsiraamat. 3rd rev. ed. Tallinn: Eesti Keele Sihtsutus. Available online at $<\mathrm{http}: /$ www.eki.ee/books/ekk09/index.php?p=1>. Accessed on 15.03.2012.

EKSS $=$ Margit Langemets, Mai Tiits, Tiia Valdre, Leidi Veskis, Ülle Viks, Piret Voll, eds. (2009) Eesti keele seletav sõnaraamat. Tallinn: Eesti Keele Sihtasutus. Available online at $<$ http://www.eki.ee/dict/ekss/ index.cgi>. Accessed on 15.03.2012.

Hough, Carole (2008) "Colours of the landscape: Old English colour terms in place-names“. In Carole P. Biggam and Christian J. Kay, eds. Progress in colour studies. Vol. 1, 181-198. Amsterdam and Philadelphia: John Benjamins.

Huldén, Lars (1989) "Svart och vitt i ortnamn”. Studia Onomastica, 169-175.

Kallasmaa, Marja (2005) “Estonian settlement names”. In Sándor Maticsák, ed. Onomastica Uralica: settlement names in the Uralian languages, 17 - 33. Debrecen and Helsinki: University of Debrecen.

Kallasmaa, Marja (2003) Läänemurde loodus- ja viljelusnimed. Eevi Ross, ed. Tallinn: Eesti Keele Sihtasutus. 
Kallasmaa, Marja (1996) Saaremaa kohanimed 1. Helmi Neetar, ed. Tallinn: Eesti Keele Instituut.

Kallasmaa, Marja (2000) Saaremaa kohanimed 2. Tiina Lias, ed. Tallinn: Eesti Keele Instituut.

Kettunen, Lauri (1955) Etymologische Untersuchung über Estnische Ortsnamen. Helsinki: Suomalainen tiedeakatemia.

Kiviniemi, Eero (1990) Perustietoa paikannimistä. Helsinki: Suomalaisen kirjallisuuden seura.

KNAB = Päll, Peeter and Indrek Hein (2001-) Place Names Database $(K N A B)$. Institute of the Estonian Language, Tallinn. Available online at $<$ http://portaal.eki.ee/knab $>$. Accessed on 15.03.2012.

Mägiste, Julius (1928) oi-, ei-deminutiivid läänemeresoome keelis: läänemeresoome nominaaltuletus 1 . Tartu: Postimees.

Oja, Vilja (2011) "Põhivärvinimetuste vasted eesti murretes". In Mari Uusküla and Urmas Sutrop, eds. Värvinimede raamat, 121-140. Tallinn: Eesti Keele Sihtasutus.

Oja, Vilja (1997) The designation of colours in Estonian dialects. Master's Thesis. Tallinn: Tallinn Pedagogical University.

Pajusalu, Karl, Tiit Hennoste, Ellen Niit, Peeter Päll, and Jüri Viikberg (2009) Eesti murded ja kohanimed. 2nd ed. Tiit Hennoste, ed. Tallinn: Eesti Keele Sihtasutus.

Pall, Valdek (1969) Põhja-Tartumaa kohanimed 1. Madis Norvik. Tallinn: Valgus.

Pall, Valdek (1977) Põhja-Tartumaa kohanimed 2. Madis Norvik. Tallinn: Valgus.

Rebassoo, Haide-Ene (1972) Laidude raamat. Tallinn: Valgus.

Saar, Evar (2008) Võrumaa kohanimede analüüs enamlevinud nimeosade põhjal ja traditsioonilise kogukonna nimesüsteem. (Dissertationes philologiae Estonicae Universitatis Tartuensis, 22). Tartu : Tartu University Press.

Sutrop, Urmas (2011) "Värvisõnad: ääremärkusi Taani hindamisraamatu Eestimaa lehtede kohta”. In Mari Uusküla and Urmas Sutrop, eds. Värvinimede raamat, 83-88. Tallinn: Eesti Keele Sihtasutus.

VMS = Pall, Valdek, ed. (1982-1989) Väike murdesõnastik. 2 vols. Tallinn: Valgus. Available online at $<\mathrm{http}$ ://portaal.eki.ee/dict/vms $>$. Accessed on 15.03.2012.

Kokkuvõte. Kaidi Rätsep: Värvinimi must eesti kohanimedes. Musta on peetud kõige sagedasemaks kohanimede värviatribuudiks. Artikkel annab lühikese ülevaate värviatribuudist must eesti kohanimedes. Uuriti Eesti Keele Instituudi kohanimekartoteeki, sellest leiti 1377 sedelit, millel olev kohanimi algas või sisaldas sõna must. Arvestamata kihelkonnasiseseid duplikaatsedeleid leiti 1081 kohanime. 
Kokku leiti 728 erinevat kohanimevarianti. Nimetavas olid kõige sagedasemateks Mustjõgi (sagedus = 26), Mustjärv (22), Mustkivi (21), Mustoja (18), Mustmägi (16). Genitiivis Musta talu (22) oli kaks korda sagedasem kui sellele järgnev Musti talu (11). Kõige sagedasem determinant oli talu (231), millele järgnesid mägi (70), mets (45) ja heinamaa (43). Tulevikku on planeeritud musta ja valge atribuutide võrdlev analüüs.

Märksõnad: kohanimed, must, värviatribuut, Eesti 